\title{
KARAKTERISTIK KEPALA DAERAH DAN AUDIT DELAY LAPORAN KEUANGAN PEMERINTAH DAERAH DI INDONESIA
}

\author{
Hesy Erlisa Frasti, Elvanya Purba Dita, Euodia Pracinthea, Ade Syahputra, \\ Arini Widyawati, dan Santoso Tri Hananto \\ Fakultas Ekonomi dan Bisnis, Universitas Sebelas Maret \\ Email: hessyfrasti@student.uns.ac.id
}

\begin{abstract}
This study aimed to examine the effects of regent/ mayor characteristics on financial statement of local government's audit delay in Indonesia. Regional head are characterized by age, educational background, executive work experience, and educational level. The population of this study were all of districts/municipalitie in Indonesia. This study uses 142 districts/municipalities as sample using purposive sampling method. The secondary data was obtained from Audit Board of the Republic of Indonesia (BPK-RI) and Ministry of Home Affairs of the Republic of Indonesia (Kemendagri). Data was analyzed using regression model. The analysis showed that the economics or accounting educational background has negatively affected on financial statement of local government's audit delay in Indonesia. However, age, executive work experience, and education level do not affect financial statement of local government's audit delay in Indonesia.
\end{abstract}

Keywords: audit delay, local government's audit delay, regent/ mayor.

Abstrak: Penelitian ini bertujuan untuk menguji pengaruh karakteristik kepala daerah terhadap audit delay laporan keuangan pemerintah daerah kabupaten/kota di Indonesia Karakteristik kepala daerah meliputi umur, latar belakang pendidikan, pengalaman kerja eksekutif, dan level pendidikan. Populasi dalam penelitian ini adalah seluruh kabupaten/kota di Indonesia. Penelitian ini menggunakan metode purposive sampling dalam memilih sampel. Data penelitian merupakan data sekunder yang diperoleh dari Badan Pemeriksa Keuangan Republik Indonesia (BPK-RI) dan Kementerian Dalam Negeri (Kemendagri). Analisis data menggunakan model regresi. Hasil analisis menunjukkan bahwa latar belakang pendidikan ekonomi/akuntansi kepala daerah berpengaruh negatif terhadap audit delay laporan keuangan pemerintah daerah di Indonesia. Sementara itu, umur, pengalaman kerja eksekutif, dan level pendidikan tidak berpengaruh terhadap audit delay laporan keuangan pemerintah daerah di Indonesia.

Kata kunci: Audit Delay, Karakteristik Kepala Daerah, Laporan Keuangan Pemerintah Daerah.

\section{PENDAHULUAN}

Ketepatwaktuan laporan keuangan merupakan salah satu aspek penting yang menjadi perhatian pengguna informasi akuntansi (Afify, 2009). Ketepatwaktuan merujuk pada penyediaan informasi kepada para pengambil keputusan sebelum informasi tersebut kehilangan kapasitasnya dalam mempengaruhi keputusan yang dibuat oleh para pengambil keputuan (Kieso, Weygandt, dan Warfield, 2010). Semakin panjangnya audit delay, maka dapat menyebabkan ketepatwaktuan penyampaian laporan keuangan semakin 
berkurang (Lase dan Sutaryo, 2014).

Laporan keuangan pemerintah daerah dituntut untuk menyediakan informasi keuangan yang relevan, sesuai dengan Standar Akuntansi Pemerintahan (SAP). Informasi keuangan akan menjadi relevan salah satunya jika disampaikan secara tepat waktu. Apabila laporan keuangan tidak disediakan tepat waktu, maka akan dapat mempengaruhi tingkat ketidakpastian dalam pengambilan keputusan (Dao dan Pham, 2014). Oleh karena itu, sudah seharusnya laporan keuangan pemerintah daerah disampaikan tepat waktu.

Namun demikian, beberapa pemerintah daerah masih terlambat menyampaikan laporan keuangannya kepada Badan Pemeriksa Keuangan (BPK) untuk diaudit. Berdasarkan data Ikhtisar Hasil Pemeriksaan Semesteran (IHPS) Semester II Tahun 20102015, pada tahun 2010 terdapat 151 dari 499 (30,26\%) pemerintah daerah yang terlambat menyampaikan laporan keuangannya ke BPK. Jumlah tersebut meningkat di tahun 2011, di mana terdapat 158 dari $516(30,62 \%)$ pemerintah daerah yang terlambat menyerahkan laporan keuangannya. Jumlah tersebut menurun di tahun 2012, di mana hanya 94 dari 520 $(18,08 \%)$ pemerintah daerah yang mengalami keterlambatan. Jumlah itu kembali meningkat di tahun 2013, di mana 108 dari 524 (20,61\%) pemerintah daerah mengalami keterlambatan, kemudian kembali menurun di tahun 2014 di mana hanya sejumlah 68 dari $524(12,98 \%)$ pemerintah daerah saja yang mengalami keterlambatan. Data keterlambatan penyampaian laporan keuangan pemerintah daerah yang paling kecil di tahun 2015, yaitu hanya sejumlah 35 dari $539(6,49 \%)$ pemerintah daerah saja yang mengalami keterlambatan. Dari data yang ada, keterlambatan yang paling besar berada pada IHPS 2011 yang merupakan hasil pemeriksaan terhadap laporan keuangan pemerintah daerah tahun 2010. Dalam hal ini, keterlambatan penyampaian laporan keuangan pemerintah daerah kepada BPK akan menambah audit delay.

Penelitian mengenai audit delay telah banyak dilakukan. Namun demikian, kebanyakan penelitan mengenai topik ini dilakukan sektor bisnis. Di Indonesia, beberapa penelitian mengenai audit delay di sektor bisnis menghasilkan temuan yang beragam. Penelitian yang dilakukan oleh Rachmawati (2008) menghasilkan temuan bahwa profitabilitas, solvabilitas, dan internal auditor berpengaruh terhadap audit delay. Sementara itu, penelitian Kartika (2009) menunjukkan hasil penelitian bahwa total aset, kerugian dan keuntungan operasi, serta pendapat auditor memiliki pengaruh yang signifikan terhadap audit delay. Di sisi lain, profitabilitas dan reputasi auditor tidak memiliki pengaruh terhadap audit delay. Lianto dan Kusuma (2010) juga meneliti mengenai faktor-faktor yang berpengaruh terhadap audit report lag yang merupakan kata lain dari audit delay. Hasilnya, profitabilitas, solvabilitas, dan umur perusahaan berpengaruh positif terhadap audit report lag, sedangkan ukuran perusahaan dan sektor industri tidak berpengaruh.

Penelitian dengan topik audit delay sektor pemerintahan belum banyak dilakukan. Beberapa penelitian sebelumnya terkait topik ini salah satunya dilakukan oleh Payne dan Jensen (2002) di Amerika bagian tenggara. Penelitian mereka menghasilkan temuan bahwa audit delay berkurang karena hal-hal berikut, seperti: insentif manajemen untuk pelaporan yang tepat waktu, sistem pelaporan keuangan yang berkualitas tinggi, serta keterikatan hutang. Sementara itu, audit delay meningkat karena karakteristik kota, seperti ukuran kota, audit yang dilakukan selama peak season auditor, qualified audit opinion, dan untuk kota yang diwajibkan mematuhi Single Audit Act. Sebelumya, McLelland dan Giroux (2000) juga meneliti hal yang serupa pada kota besar di Amerika Serikat. Penelitian tersebut mengidentifikasi beberapa faktor yang berkaitan dengan waktu yang 
dibutuhkan bagi kota- kota besar di Amerika Serikat untuk mengeluarkan laporan keuangannya.

Peneliti lain berasal dari Malaysia dan Yunani, yaitu Ahmad dan Aziz (2005) serta Cohen dan dan Leventis (2012). Ahmad dan Aziz (2005) menganalisis keterkaitan audit lags (audit delay) dengan karakteristik otoritas lokal. Hasilnya hanya tipe otoritas lokal saja yang berkaitan secara signifikan terhadap audit lags. Cohen dan Leventis (2012) menemukan bahwa oposisi politik yang kuat untuk walikota, walikota yang dipilih kembali, jumlah penduduk, keberadaan tim akuntansi internal untuk akuntansi akrual, temuan audit, dan ukuran kota, serta jumlah populasi penduduk merupakan faktor-faktor yang signifikan secara statistik dalam menjelaskan variasi dalam audit delay.

Lase dan Sutaryo (2014) mengambil topik audit delay di sektor pemerintahan, namun dari sisi karakteristik auditor di Indonesia. Penelitian tersebut menggunakan teori agensi sebagai landasan teori. Hasilnya, audit delay pada laporan keuangan pemerintah daerah dipengaruhi oleh kecakapan profesional auditor dan latar belakang pendidikan auditor. Penelitian ini juga mengambil topik mengenai audit delay di sektor pemerintahan, namun menggunakan teori upper echelons sebagai landasan teorinya. Perbedaan teori yang digunakan menjadikan variabel yang diuji menjadi berbeda. Penelitian ini bertujuan untuk menguji pengaruh karakteristik kepala daerah terhadap audit delay laporan keuangan pemerintah daerah kabupaten/kota di Indonesia Karakteristik kepala daerah meliputi umur, latar belakang pendidikan, pengalaman kerja eksekutif, dan level pendidikan.

Hasil penelitian ini diharapkan mampu menjadi masukkan bagi pemerintah dalam merancang kebijakan mengenai pengelolaan dan pelaporan keuangan pemerintah daerah, sehingga mampu meningkatkan ketepatwaktuan pelaporan keuangan pemerintah daerah dan meningkatkan relevansi laporan keuangan bagi para pemangku kepentingan. Selain itu, Hasil penelitian ini diharapkan dapat memberikan bukti empiris faktor-faktor yang merupakan karakteristik kepala daerah yang berpengaruh terhadap audit delay, sehingga dapat mengoptimalkan kinerja auditor pemerintah daerah ketika mengaudit laporan keuangan pemerintah daerah. Hasil penelitian ini diharapkan juga dapat menjadi referensi bagi penelitian-penelitian sektor publik selanjutnya, terutama penelitian yang terkait dengan audit delay.

\section{KAJIAN TEORI}

Upper Echelons. Teori upper echelons merupakan teori yang menyatakan bahwa keluaran sebuah organisasi, pilihan strategis, dan tingkat kinerja, dapat dilihat sebagai cerminan nilai dan kognitif dari manajer puncak dalam organisasi (Hambrick dan Mason, 1984). Cerminan nilai dan kognitif manajer puncak, sebagian diprediksi oleh karakteristik latar belakang manajerial. Fokus utama pada karakteristik manajerial diamati sebagai indikator yang diberikan seorang manajer ke situasi administrasi. Contoh karakteristik tersebut adalah umur, jejak fungsional, pengalam karir lain, pendidikan, akar sosioekonomi, kondisi keuangan, dan karakteristik kelompok. Penelitian upper echelons menunjukkan bahwa karakteristik eksekutif mempengaruhi hasil strategis (Hambrick, 2007).

Pada sektor publik, hasil keluaran dari organisasi dapat dilihat dari laporan keuangan pemerintah daerah dan pilihan strategis seorang manajer dapat dilihat dari tingkat ketepatan waktu penyampaian laporan keuangan pemerintah daerah. Sementara 
itu, contoh karakteristik yang bisa diambil dalam penelitian ini dan relevan dengan teori upper echelons Hambrick dan Mason (1984), yaitu umur, latar belakang pendidikan ekonomi, pengalaman eksekutif, dan tingkat pendidikan kepala daerah.

Pemeriksaan Keuangan Daerah. Dalam Pasal 1 Peraturan Badan Pemeriksa Keuangan (BPK) No. 1 Tahun 2007 tentang Standar Pemeriksaan Keuangan Negara disebutkan bahwa "Standar Pemeriksaan Keuangan Negara (SPKN) adalah patokan untuk melakukan pemeriksaan pengelolaan dan tanggung jawab keuangan negara." Sementara itu, Undangundang (UU) No. 15 Tahun 2004 tentang Pemeriksaan Pengelolaan dan Tanggung Jawab Keuangan Negara Pasal 1 ayat (1) mendefinisikan pemeriksaan (audit) sebagai berikut.

"Pemeriksaan adalah proses identifikasi masalah, analisis, dan evaluasi yang dilakukan secara independen, obyektif, dan profesional berdasarkan standar pemeriksaan, untuk menilai kebenaran, kecermatan, kredibilitas, dan keandalan informasi mengenai pengelolaan dan tanggung jawab keuangan negara."

Dalam UU No. 15 Tahun 2004 juga dijelaskan pula bahwa pemeriksaan ini terdiri atas 3 jenis, yaitu: pemeriksaan keuangan, pemeriksaan kinerja, serta pemeriksaan dengan tujuan tertentu. Dalam hal ini, standar untuk memeriksa keuangan diatur dalam Standar Pemeriksaan Keuangan. Menurut Peraturan BPK No. 1 Tahun 2007 tentang Standar Pemeriksaan Keuangan Negara, Standar Pemeriksaan Keuangan dibagi menjadi 3, yaitu: Standar Umum yang diatur dalam Pernyataan Standar Pemeriksaan (PSP) 01, Standar Pelaksanaan Pemeriksaan Keuangan yang diatur dalam PSP 02, dan Standar Pelaporan Pemeriksaan Keuangan yang diatur dalam PSP 03.

Audit Delay. Banyak peneliti yang mendefinisikan audit delay sebagai periode antara akhir tahun buku perusahaan dengan tanggal laporan audit diterbitkan (Carslaw dan Kaplan, 1991; McLelland dan Giroux, 2000; Payne dan Jensen, 2002; Johnson, Davies, dan Freeman, 2002). Audit delay atau biasa disebut juga sebagai audit report lag diukur sebagai fungsi dari jumlah hari yang berlalu dari penutupan periode akuntansi sampai dengan tanggal laporan audit diterbitkan (Bamber, Bamber, dan Schoderbek, 1993; Knechel dan Payne, 2001). Terdapat dua hal yang berpengaruh terhadap audit delay, yaitu dimulainya audit atas laporan keuangan dan lama waktu yang dibutukan dalam rangka pelaksanakan audit tersebut (Carslaw dan Kaplan, 1991).

Dalam SPKN, disebutkan bahwa salah satu dari tanggung jawab manajemen entitas yang diperiksa yaitu menyusun dan menyampaikan laporan keuangannya secara tepat waktu. Permendagri No. 13 Tahun 2006 mewajibkan kepala daerah untuk menyampaikan laporan keuangannya kepada BPK dalam jangka waktu tiga bulan setelah berakhirnya tahun anggaran. Sementara itu, UU No. 15 Tahun 2004 memberikan tenggang waktu kepada BPK maksimal dua bulan dalam memeriksa (mengaudit) laporan keuangan pemerintah daerah dan kemudian BPK harus menyerahkan laporan hasil pemeriksaan atas laporan keuangan pemerintah daerah kepada Dewan Perwakilan Rakyat Daerah (DPRD).

Audit delay pada sektor publik (pemerintahan) di Indonesia lebih tepat jika diukur berdasarkan tenggang waktu sejak tanggal laporan keuangan pemerintah daerah diterima oleh BPK sampai kepada tanggal penyerahan laporan hasil pemeriksaan atas laporan keuangan pemerintah daerah kepada DPRD. Pengukuran atas audit delay tersebut dinilai lebih tepat karena di Indonesia terdapat dua peraturan, Permendagri No. 13 Tahun 2006 dan UU No. 15 Tahun 2004, yang telah memisahkan jangka waktu penyampaian laporan keuangan dari pemerintah daerah kepada BPK dan jangka waktu pemeriksaan oleh BPK (Lase dan Sutaryo, 2014). 
Laporan keuangan dibuat dalam rangka memenuhi kebutuhan para pengambil keputusan. Dalam hal ini, ketepatan waktu merupakan salah satu karakteristik informasi dalam pelaporan keuangan (Oladipupo dan Izedomi, 2013). Informasi keuangan hanya berguna jika up to date dan dapat diperoleh oleh investor secara tempat waktu (Ahmed dan Hossain, 2010) dalam konteks bisnis. Semakin panjangnya audit delay, maka dapat menyebabkan ketepatwaktuan penyampaian laporan keuangan semakin berkurang (Lase dan Sutaryo, 2014).

Karakteristik Kepala Daerah. "Setiap daerah dipimpin oleh kepala pemerintah daerah yang disebut kepala daerah. Kepala daerah sebagaimana dimaksud pada ayat (1) untuk provinsi disebut Gubernur, untuk kabupaten disebut bupati, dan untuk kota disebut walikota." (UU No. 32 Tahun 2004 Pasal 24 ayat 1 dan 2). Menurut Hambrick dan Mason (1984), karakteristik upper echelons menjelaskan kompetensi eksekutif yaitu umur, jejak fungsional, pengalam karir lain, pendidikan, akar sosioekonomi, kondisi keuangan, dan karakteristik kelompok. Sebaa, Wallace, dam Cornelius (2009) memproksikan karakteristik manajer dengan menggunakan umur, tingkat pendidikan, pengalaman, serta aligment and performance.

Pengembangan Hipotesis Umur. Teori upper echelons menyatakan bahwa usia seorang manajer secara positif berhubungan dengan kecenderungan untuk melihat lebih banyak informasi, mengevaluasi secara akurat, dan lebih lama dalam mengambil keputusan (Hambrick dan Mason, 1984). Logikanya, seorang yang memiliki usia yang lebih matang, mereka cenderung lebih tepat waktu dalam menyampaikan laporan keuangan.

H1: Umur kepala daerah berpengaruh negatif terhadap audit delay laporan keuangan pemerintah daerah.

Latar Belakang Pendidikan. Menurut Bamber, Jiang, dan Wang (2010), manajer yang memiliki latar belakang pendidikan akuntansi atau keuangan mendukung pembuatan anggaran yang lebih detail dan teliti, sehingga dapat mengembangkan dan menciptakan kinerja yang lebih baik. Dalam penelitiannya pada pemerintah daerah di Amerika Serikat, Johnson (1998) menemukan bahwa manajer kota yang memiliki sertifikat Government Finance Officers Association (GFOA) dapat meminimalkan audit delay. Analog dengan hal tersebut, ketika kepala daerah memiliki latar belakang pendidikan ekonomi/akuntansi, diharapkan ia dapat mendukung proses pembuatan laporan keuangan maupun proses audit. Dampaknya, kepala daerah yang memiliki latar belakang pendidikan ekonomi/akuntansi diharapkan dapat mengurangi audit delay.

H2: Latar belakang pendidikan ekonomi/akuntansi kepala daerah berpengaruh negatif terhadap audit delay laporan keuangan pemerintah daerah di Indonesia.

Pengalaman Kerja Ekesekutif. Teori upper echelons menyatakan bahwa pengalaman karir lain seorang eksekutif dapat mempengaruhi nilai-nilai, gaya kognitif, dan keputusan. Eksekutif mempunyai pengalaman kognitif dan emosional selama perjalanan karir mereka (Hambrick dan Mason, 1984). Jadi, seorang kepala daerah yang pernah menjadi eksekutif atau top management di sebuah organisasi lain, akan lebih disiplin dalam menyampaikan laporan keuangan dikarenakan pengalaman masa lalu yang pernah ia peroleh.

H3: Pengalaman kerja eksekutif berpengaruh negatif terhadap audit delay laporan keuangan pemerintah daerah di Indonesia. 
Tingkat Pendidikan. Sebaa, Wallace, dan Cornelius (2009) menyatakan pendidikan terbukti sangat signifikan terhadap kinerja yang lebih tinggi. Teori upper echelons memprediksi manajer yang memegang gelar MBA mengembangkan gaya yang berbeda dari mereka yang tidak memiliki latar belakang pendidikan tersebut (Hambrick dan Mason, 1984). Artinya, semakin tinggi tingkat pendidikan kepada daerah, maka ia akan semakin patuh terhadap peraturan dan menyampaikan laporan keuangan tepat waktu.

H4: Tingkat pendidikan kepala daerah berpengaruh negatif terhadap terhadap audit delay laporan keuangan pemerintah daerah di Indonesia.

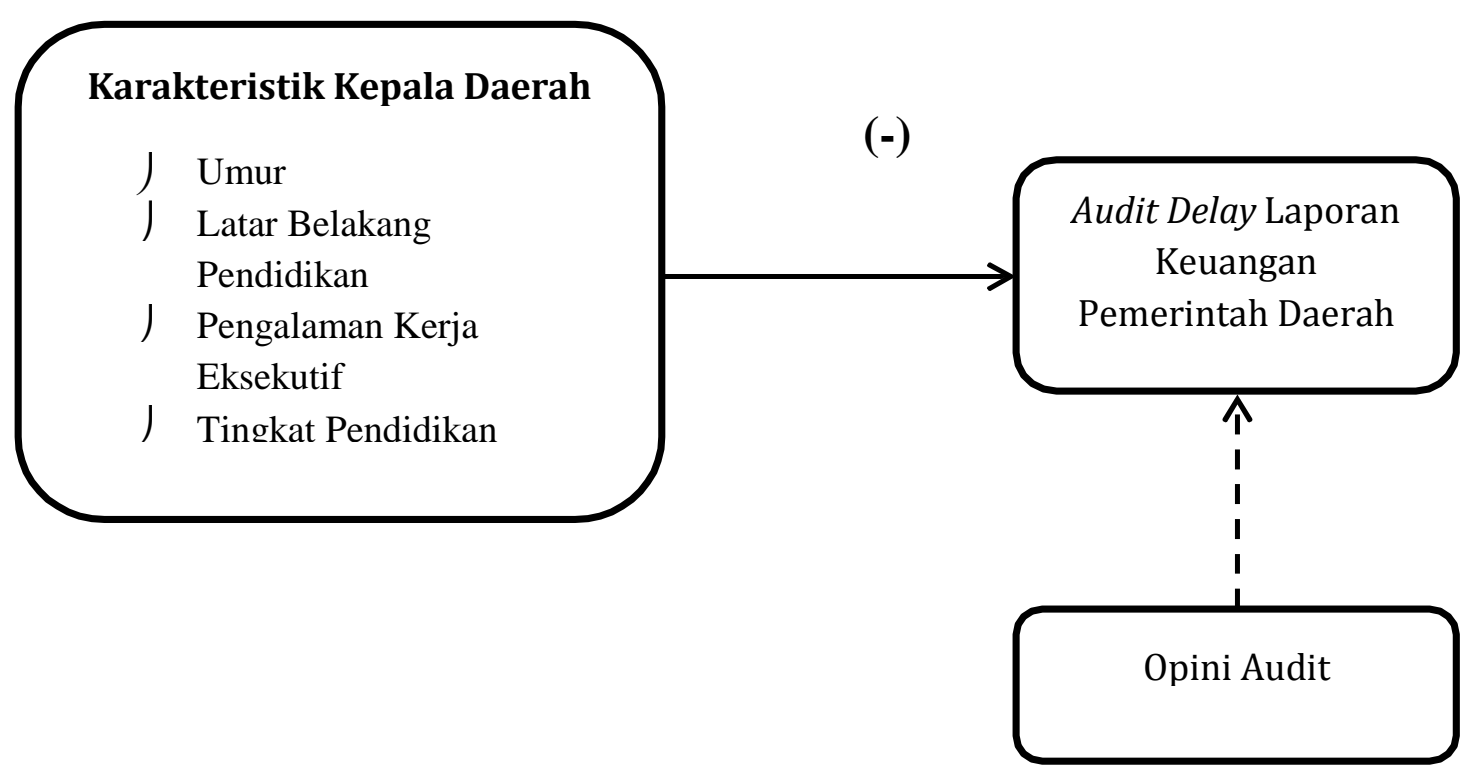

Gambar 1. Kerangka KonseptualPenelitian

Populasi dalam penelitian ini adalah seluruh pemerintah kota/kabupaten di Indonesia yang telah menyusun laporan keuangan tahun 2013 dan diaudit pada tahun 2014. Kabupaten/kota di Indonesia Indonesia yang telah menyusun laporan keuangan tahun 2013 dan diaudit pada tahun 2014. Data yang digunakan dalam penelitian ini merupakan data sekunder. Data dan sumber data yang dibutuhkan dalam penelitian ini secara ringkas disajikan dalam Tabel 1 berikut ini.

Tabel 1. Data dan Sumber Data

\begin{tabular}{rll}
\hline No & \multicolumn{1}{c}{ Data } & \multicolumn{1}{c}{ Sumber Data } \\
\hline 1. & $\begin{array}{l}\text { Laporan Hasil Pemeriksaan } \\
\text { (LHP) Tahun 2013 }\end{array}$ & $\begin{array}{l}\text { Pusat Informasi dan Komunikasi (PIK) Badan } \\
\text { Pemeriksa Keuangan (BPK) RI. }\end{array}$ \\
\hline 2. & $\begin{array}{l}\text { Ikhtisar Hasil Pemeriksaan BPK } \\
\text { Tahun 2010-2015 }\end{array}$ & Website BPK RI (www.bpk.go.id). \\
\hline 3. & $\begin{array}{l}\text { Data Karakteristik Kepala } \\
\text { Daerah }\end{array}$ & $\begin{array}{l}\text { Buku Profil Kepala Daerah Hasil Pemilukada } \\
2010 .\end{array}$ \\
\hline
\end{tabular}

Sumber: penulis

Pemilihan sampel berdasarkan metode purposive sampling. Adapun kriteria yang 
digunakan untuk menentukan sampel penelitian ini, antara lain sebagai berikut. (a) Pemerintah daerah yang menyusun laporan keuangan untuk tahun 2013 dan diaudit oleh BPK pada tahun 2014; (b) Pemerintah daerah yang memiliki data-data yang diperlukan dalam pengukuran variabel penelitian ini. Sementara itu, pengukuran variabel dalam penelitian ini disajikan dalam Tabel 2 . berikut ini.

Tabel 2. Pengukuran Variabel

\begin{tabular}{cll}
\hline No & \multicolumn{1}{c}{ Variabel } & \multicolumn{1}{c}{ Pengukuran } \\
\hline 1. & Audit delay & $\begin{array}{l}\text { Jangka waktu antara penyampaian laporan keuangan } \\
\text { pemerintah daerah kepada BPK dan penyerahan laporan hasil } \\
\text { pemeriksaan (LHP) BPK atas laporan keuangan pemerintah } \\
\text { daerah kepada DPRD. }\end{array}$ \\
\hline 2. & Umur kepala daerah & $\begin{array}{l}\text { Selisih antara tahun penelitian (2013) dan tahun lahir kepala } \\
\text { daerah. }\end{array}$ \\
\hline 3. & $\begin{array}{l}\text { Latar } \\
\text { belakang } \\
\text { pendidikan }\end{array}$ & $\begin{array}{l}\text { "1" untuk kepala daerah lulusan ekonomi/akuntansi, "0" untuk } \\
\text { jurusan nonekonomi/nonakuntansi }\end{array}$ \\
\hline 4. & $\begin{array}{l}\text { Pengalaman } \\
\text { kerja eksekutif }\end{array}$ & $\begin{array}{l}\text { Jumlah pengalaman kepala daerah dalam menjabat sebagai } \\
\text { pemimpin suatu organisasi. }\end{array}$ \\
\hline 5. & Tingkat pendidikan & $\begin{array}{l}\text { "0" untuk tingkat belakang pendidikan di bawah SMA, "1" } \\
\text { untuk SMA, "2" diploma, "3" untuk S1, "4" untuk S2, dan "5" } \\
\text { untuk S3. }\end{array}$ \\
\hline
\end{tabular}

Sumber: penulis

\section{Model Regresi}

$$
A U D=\alpha+\beta 1 \text { Ln AGE }+\beta 2 \text { BACK }+\beta 3 \text { EKS }+\beta 4 \mathrm{LVL}+\beta 5 \text { OPINI }+\varepsilon
$$

Keterangan: AUD : Audit delay; AGE : Umur; BACK : Latar belakang pendidikan; EKS : Pengalaman kerja eksekutif; LVL : Tingkat pendidikan; OPINI : Opini audit; $\alpha$ :

Konstanta; $\beta 1 \ldots \beta 4$ : Koefisien regresi; $\varepsilon$ : Error

Penentuan Sampel. Dari populasi yang ada, sampel yang digunakan dalam penelitian ini yaitu sebagai berikut:

Tabel 3. Penentuan Sampel

\begin{tabular}{lc}
\hline \multicolumn{1}{c}{ Kriteria Sampel } & Jumlah \\
\hline $\begin{array}{l}\text { Kabupaten/kota di Indonesia yang menyusun laporan keuangan } \\
\text { untuk tahun } 2013\end{array}$ & 508 \\
Data tidak lengkap & $(354)$ \\
Outlier & $(12)$ \\
Total Sampel & 142 \\
\hline
\end{tabular}

Sumber: Penulis

Berdasarkan Tabel 3, total sampel akhir yang digunakan dalam penelitian ini sejumlah pemerintah daerah kabupaten/kota di Indonesia tahun 2013. 


\section{HASIL DAN PEMBAHASAN}

Statistik Deskriptif. Tabel 4 menunjukkan hasil statistik deskriptif data penelitian. Ratarata audit delay laporan keuangan pemerintah daerah kabupaten/kota di Indonesia (AUD) sebesar 60,37 hari. Artinya, rata-rata jangka waktu penyampaian laporan keuangan pemerintah daerah tahun 2013 kepada BPK dan penyerahan laporan hasil pemeriksaan (LHP) BPK atas laporan keuangan pemerintah daerah kepada DPRD kurang lebih selama 2 bulan. Jangka waktu tersebut tersebut relatif lama apabila mengacu pada UU No. 15 Tahun 2004. Menurut UU tersebut, pemerintah memberikan tenggang waktu kepada BPK maksimal dua bulan dalam memeriksa (mengaudit) laporan keuangan pemerintah daerah dan kemudian BPK harus menyerahkan laporan hasil pemeriksaan atas laporan keuangan pemerintah daerah kepada DPRD. Artinya, sebagian laporan keuangan pemerintah daerah terlambat diserahkan kepada DPRD.

Tabel 4. Statistik Deskripti

\begin{tabular}{cccccc}
\hline Variabel & N & Minimum & Maximum & Mean & $\begin{array}{c}\text { Std. } \\
\text { Deviation }\end{array}$ \\
\hline AUD & 142 & 26 & 100 & 60,37 & 11,515 \\
AGE & 142 & 30 & 75 & 51,81 & 7,824 \\
EKS & 142 & 0 & 8 & 2,16 & 2,159 \\
LVL & 142 & 1 & 5 & 3,65 & 0,764 \\
OPINI & 142 & 1 & 4 & 3,24 & 0,816 \\
Valid N & 142 & & & & \\
(listwise) & & & & & \\
\hline
\end{tabular}

Sumber: Data diolah.

Hasil analisis menunjukkan bahwa rata-rata umur kepala daerah sekitar 52 tahun, dengan kepala daerah termuda berusia 30 tahun, yaitu kepala daerah Kabupaten Tanah Bumbu dan kepala daerah tertua berusia 75 tahun di tahun 2013, yaitu kepala daerah Kabupaten Paser. Untuk pengalaman eksekutif, rata-rata kepala daerah pernah menjabat sebagai pemimpin suatu organisasi sejumlah 2 kali dengan rata-rata level pendidikan kepala daerah kabupaten/kota di Indonesia yaitu berada di antara level S1 dan S2. Sementara itu, opini audit yang diberikan BPK untuk laporan keuanan kabupaten/kota di Indonesia rata-rata adalah Wajar Dengan Pengecualian(WDP).

Uji Asumsi Klasik. Uji Normalitas. Uji normalitas bertujuan untuk menguji apakah dalam sebuah model regresi, variabel dependen, variabel independen, atau keduanya mempunyai distribusi normal atau tidak normal. Uji normalitas dalam penelitian ini menggunakan pengujian One-Sample Kolmogorov-Smirnov Test.

Pada Tabel 5, hasil uji normalitas menunjukkan signifikansi 0,07. Oleh karena level signifikansi lebih besar dari 0,05 , artinya data dalam penelitian terdistribusi secara normal.

a. Uji Autokorelasi. Uji Autokorelasi bertujuan menguji apakah model regresi linier ada korelasi antara kesalahan pengganggu pada periode t dengan kesalahan pengganggu pada periode sebelumnya. Uji normalitas dalam penelitian ini menggunakan pengujian Durbin Watson. 
Tabel 5. Uji Normalitas One-Sample Kolmogorov-Smirnov Test

\begin{tabular}{llr}
\multicolumn{2}{c}{ Kolmogorov-Smirnov Test } \\
\hline & & $\begin{array}{c}\text { Unstandardized } \\
\text { Residual }\end{array}$ \\
\hline $\mathrm{N}$ & & 142 \\
Normal Parameters & Mean &, 0000000 \\
& Std. Deviation &, 17236331 \\
& Absolute &, 109 \\
Most Extreme & Positive &, 096 \\
Differences & &,- 109 \\
& Negative & 1,295 \\
Kolmogorov-Smirnov Z & &, 070 \\
Asymp. Sig. (2-tailed) & & \\
a. Test distribution is Normal. & \\
b. Calculated from data. &
\end{tabular}

Sumber: Data diolah.

Tabel 6. Uji Autokorelasi Durbin Watson Model Summary b

\begin{tabular}{|c|c|c|c|c|c|}
\hline Model & $\mathrm{R}$ & R Square & $\begin{array}{c}\text { Adjusted R } \\
\text { Square }\end{array}$ & $\begin{array}{c}\text { Std. Error of the } \\
\text { Estimate }\end{array}$ & $\begin{array}{l}\text { Durbin- } \\
\text { Watson }\end{array}$ \\
\hline 1 &, $402^{\mathrm{a}}$ &, 162 & ,131 & ,1755032 & 1,843 \\
\hline
\end{tabular}

1. Predictors: (Constant), OPINI, BACK, EKS, LVL, LN AGE

2. Dependent Variable: LN AUD

Sumber: Data diolah.

Hasil uji autokorelasi dengan sampel 142 dan variabel penjelas sebanyak 5 menunjukkan nilai Durbin Watson sebesar 1,843. Artinya, model bebas dari autokorelasi karena nilai Durbin-Watson berada di antara du $(1,6536)$ dan dL $(1,7992)$.

b. Uji Multikolineritas. Uji multikolinearitas bertujuan untuk menguji apakah model regresi ditemukan adanya korelasi antar variabel penjelas. Untuk mendeteksi apakah terjadi masalah multikol dapat melihat nilai tolerance dan lawannya variance inflation factor (VIF). Nilai VIF yang diperkenankan adalah 10, jika nilai VIF lebih dari 10 maka dapat dikatakan terjadi multikolinearitas, yaitu terjadi hubungan yang cukup besar antara variabel-variabel penjelas, dan angka tolerance mempunyai angka $>0,10$, maka variabel tersebut tidak mempunyai masalah multikolinearitas dengan variabel penjelas lainnya.

Pada Tabel 7, hasil pengujian menunjukkan bahwa nilai tolerance dari seluruh variabel penjelas $>0,10$ dan nilai VIF $<10$, maka artinya model regresi tidak mengandung multikolinearitas.

c. Uji Heteroskedastisitas. Uji ini bertujuan untuk menguji apakah faktor pengganggu mempunyai variasi sama atau tidak. Uji heteroskedastisitas dalam penelitian ini 
menggunakan Uji Park.

Tabel 7. Uji Multikoliearitas

\begin{tabular}{lccc}
\hline \multicolumn{1}{c}{ Variabel Penjelas } & Tolerance & VIF & Kesimpulan \\
\hline Umur & 0,936 & 1,068 & Tidak ada multikolinearitas \\
$\begin{array}{l}\text { Latar Belakang } \\
\text { Pendidikan }\end{array}$ & 0,926 & 1,080 & Tidak ada multikolinearitas \\
\hline \multicolumn{1}{c}{ Variabel Penjelas } & Tolerance & VIF & Kesimpulan \\
\hline $\begin{array}{l}\text { Pengalaman Kerja } \\
\text { Eksekutif }\end{array}$ & 0,969 & 1,032 & Tidak ada multikolinearitas \\
Tingkat Pendidikan & 0,953 & 1,049 & Tidak ada multikolinearitas \\
Opini & 0,979 & 1,022 & Tidak ada multikolinearitas \\
\hline
\end{tabular}

Sumber: Data diolah.

Hasil pengujian menunjukkan nilai signifikansi dari seluruh variabel pejelas tidak ada yang signifikan secara statistik, sehingga dapat disimpulkan bahwa model ini tidak mengalami masalah heteroskedastisitas.

Tabel 8. Uji Park

\begin{tabular}{|c|c|c|c|c|c|}
\hline \multicolumn{6}{|c|}{ Coefficients $^{\mathrm{a}}$} \\
\hline \multirow[t]{2}{*}{ Model } & \multicolumn{2}{|c|}{ Unstandardized Coefficients } & $\begin{array}{l}\text { Standardized } \\
\text { Coefficients }\end{array}$ & \multirow[t]{2}{*}{$\mathrm{t}$} & \multirow[t]{2}{*}{ Sig. } \\
\hline & B & Std. Error & Beta & & \\
\hline (Constant) & $-12,564$ & 4,973 & & $-2,527$ & ,013 \\
\hline LN AGE & 2,010 & 1,230 &, 140 & 1,634 & , 105 \\
\hline BACK &, 603 & ,398 &, 131 & 1,515 &, 132 \\
\hline \multicolumn{6}{|l|}{2} \\
\hline EKS &, 052 & ,087 & ,051 & ,601 & ,549 \\
\hline LVL & ,129 & 247 & ,044 & ,523 & 602 \\
\hline OPINI &,- 446 & ,228 &,- 164 & $-1,952$ & 053 \\
\hline
\end{tabular}

a. Dependent Variable: RES_3

Sumber: Data diolah.

Hasil Pengujian Regresi. Hasil uji F pada Tabel 9 menunjukkan bahwa persamaan regresi memiliki nilai signifikansi yang lebih kecil dari 5\%, artinya persamaan regresi layak (fit) digunakan dalam penelitian. Hasil pengujian juga menunjukkan adjusted $R$ squared sebesar 0,131. Artinya, 13,1\% variabel audit delay dapat dijelaskan oleh karakteristik kepala daerah, sedangkan sisanya sebesar 86,9\% dijelaskan oleh variabelvariabel lain di luar persamaan.

Hasil uji t menunjukkan bahwa hanya variabel independen latar belakang pendidikan ekonomi/akuntansi kepala daerah saja yang berpengaruh terhadap audit delay dengan koefisien regresi sebesar -0,111 dan signifikansi 0,001. Karena level signifikansi di bawah 5\% dan koefisien regresi menunjukkan arah negatif, maka hipotesis ketiga diterima. Latar belakang pendidikan ekonomi/akuntansi kepala daerah berpengaruh negatif terhadap 
audit delay laporan keuangan pemerintah daerah di Indonesia.

Tabel 9. Hasil Pengujian Regresi

\begin{tabular}{lccc}
\hline \multirow{1}{*}{ Variabel } & \multicolumn{3}{c}{ AUD } \\
\cline { 2 - 4 } (Constant) & B & Sig. \\
LN AGE & 3,698 & & 0,000 \\
BACK & 0,102 & & 0,304 \\
EKS & $-0,111$ & & $0,001^{* * *}$ \\
LVL & 0,011 & & 0,130 \\
OPINI & 0,036 & & $0,071^{*}$ \\
R Square & $-0,040$ & & $0,031^{* *}$ \\
Adj R Square & & 0,162 & \\
F-test & \multicolumn{3}{c}{0,131} \\
Sig F-test & \multicolumn{3}{c}{5,247} \\
\hline Subrt & $0,000^{* * *}$ \\
\hline
\end{tabular}

Sumber: Data diolah.

Temuan ini mendukung argumen Bamber, Jiang, dan Wang (2010) bahwa manajer yang memiliki latar belakang pendidikan akuntansi atau keuangan mendukung pembuatan anggaran yang lebih detail dan teliti, sehingga dapat mengembangkan dan menciptakan kinerja yang lebih baik. Dalam penelitian ini, kinerja yang lebih baik mengacu pada semakin berkurangnya audit delay.

Sementara itu, umur kepala daerah tidak berpengaruh terhadap audit delay. Artinya, hipotesis pertama dalam penelitian ini ditolak. Temuan tersebut mendukung argumen Sebaa, Wallace, dan Cornelius (2009) yang mengatakan usia bukanlah karakteristik yang signifikan dalam menentukan kinerja yang lebih tinggi. Namun demikian, hal tersebut tidak mendukung teori upper echelons menyatakan bahwa usia seorang manajer secara positif berhubungan dengan kecenderungan untuk melihat lebih banyak informasi, mengevaluasi secara akurat, dan lebih lama dalam mengambil keputusan (Hambrick dan Mason, 1984). Penyebabnya mungkin karena di sektor privat, umur manajer mengacu kepada pengalaman menjabat yang lebih lama, sehingga manajer lebih bisa melihat lebih banyak informasi dan mengevaluasi secara akurat. Sementara itu, sektor publik memiliki karakteristik khusus, seperti kepala daerah hanya bisa memimpin daerah selama maksimal 2 periode (atau selama 10 tahun). Artinya, meskipun seorang kepala daerah telah berumur, namun ia tetaplah hanya bisa memimpin daerahnya selama maksimal 10 tahun, sehingga tidak berpengaruh terhadap kinerjanya, termasuk terhadap audit delay. Apalagi jika kepala daerah yang berumur tersebut tidak memiliki background pendidikan ekonomi/akuntansi.

Serupa dengan umur kepala daerah, pengalaman kerja eksekutif kepala daerah juga tidak berpengaruh terhadap audit delay. Artinya, hipotesis kedua dalam penelitian ini ditolak. Temuan dalam penelitian ini tidak mendukung teori upper echelons yang menyatakan bahwa pengalaman karir lain seorang eksekutif dapat mempengaruhi nilainilai, gaya kognitif, dan keputusan. Eksekutif mempunyai pengalaman kognitif dan emosional selama perjalanan karir mereka (Hambrick dan Mason, 1984). Penyebabnya mungkin karena memimpin daerah berbeda dengan memimpin organisasi lain yang levelnya lebih kecil. Apalagi terkait dengan proses audit yang memang membutuhkan pengetahuan seputar ekonomi/akuntansi. 
Karakteristik kepala daerah terakhir yang diuji dalam penelitian ini, yaitu tingkat pendidikan kepala daerah juga tidak berpengaruh terhadap audit delay. Artinya, hipotesis keempat dalam penelitian ini ditolak. Hasil penelitian tidak mendukung temuan Sebaa, Wallace, dan Cornelius (2009) menyatakan pendidikan terbukti sangat signifikan terhadap kinerja yang lebih tinggi. Penyebabnya mungkin karena kepala daerah yang tingkat pendidikan yang tinggi namun tidak memiliki latar belakang pendidikan ekonomi/akuntansi pun mungkin kurang memahami mekanisme pelaporan keuangan maupun pemeriksaan (audit) terhadap laporan keuangan pemerintah daerah yang ia pimpin. Berbeda jika seorang kepala daerah memiliki latar belakang pendidikan akuntansi, maka minimal ia memahami tentang mekanisme pelaporan dan audit atas laporan keuangan pemerintah daerah, sehingga mampu mengurangi audit delay.

\section{PENUTUP}

Simpulan. Penelitian ini bertujuan untuk menguji pengaruh karakteristik kepala daerah kabupaten/kota terhadap audit delay laporan keuangan pemerintah daerah di Indonesia Hasil analisis menunjukkan bahwa latar belakang pendidikan ekonomi/akuntansi kepala daerah berpengaruh negatif terhadap audit delay laporan keuangan pemerintah daerah di Indonesia. Sementara itu, karakteristik kepala daerah lain berupa umur, pengalaman kerja eksekutif, dan level pendidikan tidak berpengaruh terhadap audit delay laporan keuangan pemerintah daerah di Indonesia.

Saran. Penelitian ini memiliki beberapa keterbatasan, seperti hanya memasukkan karakteristik kepala daerah sebagai variabel independen yang kurang berpengaruh langsung terhadap audit delay. Selain itu penelitian ini juga hanya menggunakan data karakteristik kepala daerah yang bersumber dari Buku Profil Kepala Daerah, belum mencari dari sumber lain seperti website pemerintah daerah atau sumber lain yang terpercaya. Penelitian selanjutnya diharapkan menambahkan variabel lain yang mungkin terkait langsung dengan audit delay, seperti jumlah temuan audit dan mencari data karakteristik kepala daerah melalui sumber lain yang valid, sehingga menggeneralisasi pengaruh karakteristik kepala daerah terhadap audit delay.

\section{DAFTAR RUJUKAN}

Afify, H. A. E. (2009) "Determinants of Audit Report Lag: Does Implementing Corporate Governance Have Any Impact? Empirical Evidence from Egypt". Journal of Applied Accounting Research, 10(1),56-86.

Ahmad, N. dan A. A. Aziz. (2005) "Timeliness of Local Authorities' Financial Reports". Journal of Financial Reporting and Accounting, 3(1), $111-127$.

Ahmed, A. A. A. dan M. S. Hossain. (2010) Audit Report Lag: A Study of the Bangladeshi Listed Companies. ASA University Review, 4 (2), 49-56.

Badan Pemeriksa Keuangan. (2011) Ikhtisar Hasil Pemeriksaan Semester II Tahun 2010. www.bpk.go.id. Diunduh pada tanggal: 19 Maret 2015.

Badan Pemeriksa Keuangan. (2012) Ikhtisar Hasil Pemeriksaan Semester II Tahun 2011. www.bpk.go.id. Diunduh pada tanggal: 19 Maret 2015.

Badan Pemeriksa Keuangan. (2013) Ikhtisar Hasil Pemeriksaan Semester II Tahun 2012. 
www.bpk.go.id. Diunduh pada tanggal: 19 Maret 2015.

Badan Pemeriksa Keuangan. (2014) Ikhtisar Hasil Pemeriksaan Semester II Tahun 2013. www.bpk.go.id. Diunduh pada tanggal: 19 Maret 2015.

Badan Pemeriksa Keuangan. (2015) Ikhtisar Hasil Pemeriksaan Semester II Tahun 2014. www.bpk.go.id. Diunduh pada tanggal: 19 Maret 2015.

Badan Pemeriksa Keuangan. (2016) Ikhtisar Hasil Pemeriksaan Semester II Tahun 2015. www.bpk.go.id. Diunduh pada tanggal: 11 Agustus 2016.

Bamber, E. M., L. S. Bamber, dan M. P. Schoderbek, (1993) "Audit Structure and Other Determinants of Audit Report Lag: An Empirical Analysis, Auditing": A Journal of Practice \& Theory, 12(1), 1-23.

Bamber, L. S., J. Jiang, dan I. Y. Wang. (2010) "What's My Style? The Influence of Top Managers on Voluntary Corporate Financial Disclosure". The Accounting Review 85(4), 1131-1162.

Carslaw, C. A. dan S. E Kaplan,. (1991) "An Examination of Audit Delay: Further Evidence from New Zealand". Accounting and Business Research 22(85), 21-32.

Cohen, S. dan S. Leventis. (2012) Effects of Municipal, Auditing and Political Factors on Audit Delay. Accounting Forum, 37(1), 40-53.

Dao, M. dan T. Pham. (2014) "Audit Tenure, Auditor Specialization and Audit Report Lag”. Managerial Auditing Journal, 29(6), 490-512.

Ghozali, I. (2012) Aplikasi Analisis Multivariate dengan Program IBM SPSS 20. Edisi 6. Semarang: Badan Penerbit Universitas Diponegoro.

Hambrick, D. C. (2007) "Upper Ehelon Theory: An Update". Academy of Management Review. 32(2), 334-343.

Hambrick, D. C. dan P. A. Mason. (1984) "Upper Echelons: The Organization as a Reflection of its Top Managers". The Academy of Management Review 9(2), 193206.

Johnson, L. E., S. P. Davies, dan R. J. Freeman. (2002) "The Effect of Seasonal Variations in Auditor Workload on Local Government Audit Fees and Audit Delay". Journal of Accounting and Public Policy 21(4), 395-422.

Kartika, A. (2009) "Faktor-faktor yang Mempengaruhi Audit Delay di Indonesia (Studi Empiris pada Perusahaan-perusahaan LQ 45 yang Terdaftar di Bursa Efek Jakarta)". Jurnal Bisnis dan Ekonomi 16(1), 1-17.

Kieso, E. D., J. J. Weygandt, dan T. D. Warfield. (2012) Intermediate Accounting. IFRS Edition. Volume 2. USA: John Wiley dan Sons.

Knechel, W. R. dan L. F. Payne. (2001) "Additional Evidence on Audit Report Lag. Auditing" A Journal of Practice \& Theory, 20(1), 137-146.

Lase, Y. dan Sutaryo. (2014) Pengaruh Karakteristik Auditor terhadap Audit Delay Laporan Keuangan Pemerintah Daerah. Simposium Nasional Akuntansi XVII. Mataram.

Lianto, N. dan B. H. Kusuma. (2010) "Faktor-faktor yang Berpengaruh terhadap Audit Report Lag”. Jurnal Bisnis dan Akuntansi, 12(2): 97-106.

McLelland, A.J. dan G. Giroux. (2000) "An Empirical Analysis of Auditor Report Timing by Large Municipalities". Journal of Accounting and Public Policy, 19(3), 263-281.

Oladipupo, A. O. dan F. Izedomi. (2013) Global Demand for Timely Financial Reporting: How Prepared are Nigerian Companies?. Research Journal of Finance and Accounting, 4(8). pp. 63-75. 
Payne, J. L. dan K. L. Jensen. (2002) “An Examination of Municipal Audit Delay". Journal of Accounting and Public Policy, 21(1), 1-29.

Rachmawati, S. (2008) "Pengaruh Faktor Internal dan Eksternal Perusahaan terhadap Audit Delay dan Timeliness". Jurnal Akuntansi dan Keuangan, 10(1), 1-10.

Sebaa, A. A., J. Wallace., dan N. Cornelius. (2009) "Managerial Characteristics, Strategy and Performance in Local Government". Measuring Business Excellence, 13(4), 12-21.

Peraturan Badan Pemeriksa Keuangan No. 1 Tahun 2007 tentang Standar Pemeriksaan Keuangan Negara.

Peraturan Menteri Dalam Negeri Nomor 13 Tahun 2006 tentang Pedoman Pengelolaan Keuangan Daerah.

Peraturan Menteri Dalam Negeri Nomor 64 Tahun 2013 tentang Penerapan Standar Akuntansi Pemerintahan Berbasis Akrual pada Pemerintah Daerah.

Peraturan Pemerintah No. 8 Tahun 2006 tentang Pelaporan Keuangan dan Kinerja Instansi Pemerintah.

Peraturan Pemerintah No. 71 Tahun 2010 tentang Standar Akuntansi Pemerintahan.

Undang-undang No. 15 Tahun 2004 tentang Pemeriksaan Pengelolaan dan

Tanggung Jawab Keuangan Negara.

Undang-undang No. 32 Tahun 2004 tentang Pemerintahan Daerah. 